\title{
Mission Impossible:
}

\section{Hammarskjold and the UN Mandate for the Congo (1960-1961)}

\author{
Henning Melber ${ }^{\text {abc }}$
}

\begin{abstract}
${ }^{a}$ Nordic Africa Institute, Uppsala, Sweden; ${ }^{b}$ Department of Political Sciences, University of Pretoria, Pretoria, South Africa; ${ }^{\circ}$ Centre for Africa Studies, University of the Free State, Bloemfontein, South Africa
\end{abstract}

Correspondence to: Henning Melber Nordic Africa Institute, PO Box 1703, SE-75236, Uppsala, Sweden. henning.melber@nai.uu.se

\begin{abstract}
The Congo's independence in 1960 was followed by unrest, intervention by Belgian troops, and the secession of the Katanga province. The United Nations Security Council authorized Secretary-General Dag Hammarskjold to send a peacekeeping force to support the Congolese government, but with the proviso not to interfere in domestic politics. This contradiction created a mission impossible. Conflicting interpretations of the mandate were complicated by the member states' geostrategic interests at the height of the Cold War. The mandate that Hammarskjold had boldly secured was contested and led both the Soviet Union and the Western alliances of states to distrust the role of the secretary-general.
\end{abstract}

KEYWORDS Hammarskjold; peacemaking mandate; Republic of the Congo; UN secretary-general

\section{Introduction}

The crisis in the Republic of the Congo in 1960 was the biggest test of Dag Hammarskjold's diplomacy as United Nations (UN) secretary-general, and his last. This article discusses the first UN mandate for peacekeeping in the Congo and its troubled implementation in 1960-1961, focusing particularly on the role of the UN secretariat and especially its secretary-general. In response to a call for military assistance by the Congolese government, Hammarskjold obtained a UN Security Council mandate to resolve the civil unrest that had erupted after the proclamation of independence from Belgium on June 30, 1960. ${ }^{1}$ Believing that this mandate had to be guided by the UN Charter as the only valid reference point and normative framework, he defined the mandate as authorization to act with relative autonomy from any individual state interests. But the Congo mission soon attracted criticism, particularly from the Soviet Union, which demanded Hammarskjold's resignation. Under increasing pressure to justify the Congo operation and defend his role, Hammarskjold made more than 40 interventions in Security Council and General Assembly debates from mid-1960 to his untimely death September 17-18, 1961. He was adamant that 
the interpretation of a Council mandate should lie with the UN secretariat. He held a strong conviction that the secretary-general had not only the right but also the duty and responsibility to act in the spirit of the UN Charter - if necessary with a degree of autonomy and guided by his loyalty to the Charter alone. He was adamant that, as Article 100(1) of the charter stipulates, neither the secretary- general nor the secretariat staff in performing their duties shall "seek or receive instructions from any government or from any other authority external to the Organization." This conviction, as the case of the Congo intervention testifies, collided with the big powers' ideas about how the mandate should be interpreted.

In his introduction to the annual report to the UN for 1959-1960 Hammarskjold said:

It is my firm conviction that any result bought at the price of a compromise with the principles and ideals of the Organization, either by yielding to force, by disregard of justice, by neglect of common interests or by contempt for human rights, is bought at too high a price. That is so because a compromise with its principles and purposes weakens the Organization in a way representing a definite loss for the future that cannot be balanced by any immediate advantage achieved. ${ }^{2}$

His efforts to steer the UN in the Congo crisis entailed continuous mediation between many actors, both Congolese and powerful external players, in the midst of escalating Cold War antagonisms. Maintaining a nonpartisan course was extremely difficult, and the ambiguities of the mandate made it more so. The ambiguities stemmed from the necessity to avoid any veto of the council resolutions but gave rise to conflicting interpretations and thus impeded implementation.

Hammarskjold found himself navigating the Congo mission through rough waters, assailed by strong winds from all directions. Failure seemed almost preordained, and the costs were very high: the kidnapping and assassination of Patrice Lumumba in a CIA-related operation by the Katangese-Belgian alliance with the involvement of mercenaries in 1960-1961, the loss of his own life and that of 15 others when their plane crashed during the night of September 17-18, 1961, and the deaths of many more civilians and soldiers on all sides of the conflict, including many Blue Helmets. The mission failed to bring peace to the Congo, although it managed to keep the conflict within the Congolese borders.

\section{Formulating and implementing the mandate}

President Joseph Kasavubu and Prime Minister Patrice Lumumba led the Congolese government when independence was declared June 30, 1960. Only days into national sovereignty, however, Congolese soldiers embarked on a series of mutinies against the Belgian officers still in control of the military. On July 10 the Belgian government dispatched paratroopers to the Katanga province and other places. Katanga's mineral wealth was of major geostrategic importance and exploited mainly by the Belgian mining company Union Miniere du Haut Katanga and other Western mining companies. The Belgian military intervention, requested by the Katangese provincial president Moise Tshombe, was in violation of an agreement signed between Belgium 
and the Congo at independence. On July 11 Tshombe proclaimed Katanga's independence from the Congo. This secession and the subsequent military clashes with Belgian paratroopers motivated Kasavubu and Lumumba to request, in a telegram of July 12 addressed to the UN secretary-general, an "urgent dispatch by the United Nations of military assistance ... to protect the national territory of the Congo against the present external aggression."3 They blamed Belgium for masterminding the secession of Katanga. In a follow-up cable to the secretary-general July 13, they added that the purpose of the requested assistance was "not to restore the internal situation in Congo but rather to protect the national territory against acts of aggression committed by Belgian metropolitan troops," that it related "only to a United Nations force consisting of military personnel from neutral countries," and that if the assistance was not received "without delay" the Republic of the Congo would be "obliged to appeal to the Bandung treaty powers."

This clarification was intended to eliminate the risk that UN forces might collaborate with the Belgian military on the ground. Hammarskjold acted immediately. For the first time invoking Article 99 of the charter, ${ }^{5}$ he called an urgent meeting of the security council. He argued that the conflict that had developed in the Congo had "an important international bearing" as it was of a nature that could not "be disregarded by other countries." ${ }^{\prime 6}$ He said the presence of the Belgian troops could not be "accepted as a satisfactory stopgap arrangement pending the reestablishment of order through the national security force." He added that the UN peacekeeping force would not be authorized to take "action beyond selfdefense" or "any action which would make them a party to internal conflicts." He expressed his intention "to get, in the first place, assistance from African nations" and finally urged the council "to act with the utmost speed."

After intense negotiations, the following draft resolution was tabled by Tunisia:

The Security Council,

Considering the report of the Secretary-General on a request for United Nations action in relation to the Republic of the Congo,

Considering the request for military assistance addressed to the Secretary- General by the President and the Prime Minister of the Republic of the Congo (S/4382),

(1) Calls upon the Government of Belgium to withdraw its troops from the territory of the Republic of the Congo;

(2) Decides to authorize the Secretary-General to take the necessary steps, in consultation with the Government of the Republic of the Congo, to provide the government with such military assistance as may be necessary until, through the efforts of the Congolese government with the technical assistance of the United Nations, the national security forces may be able, in the opinion of the government, to meet fully their tasks;

(3) Requests the Secretary-General to report to the Security Council as appropriate.

The text was argued over but finally adopted as Security Council Resolution 143 
(1960) by eight votes in favor (the United States, the USSR, Argentina, Ceylon, Ecuador, Italy, Poland, and Tunisia) with the abstention of France, the UK, and Nationalist China. But the U.S. and Soviet permanent representatives disagreed in their interpretations: the former said the resolution "made Belgian withdrawal contingent upon creation and deployment of the UN Force," whereas the latter said it "should be interpreted as calling for immediate and unconditional Belgian withdrawal."

The wording of the resolution was a necessary compromise to avoid veto by any of the permanent members. But from the beginning it created misunderstandings about the import of the mandate:

The miracle of the success of the Security Council could not hide the weaknesses of the text that was agreed upon, despite the Cold War constraints of the time, precisely because it left room for at least two different interpretations. According to Western countries and, to a certain extent, to the Secretary-General, the UN operation should assist the Congolese government to maintain internal order, whereas the Soviet Union, Poland and Tunisia thought of it as an instrument to help the Congolese government to face Belgian aggression. ${ }^{\text {? }}$

Despite the differing interpretations, the resolution created the impression of a kind of common denominator and authorized the UN military presence in the country, but it did not give clear and concrete guidance. While the resolution provided space for maneuvering — and at times was used thus by Hammarskjold - it carried the risk that, in the absence of clarity, all the parties at various times would be critical of what the UN secretariat did. Brian Urquhart notes that "in directing the Secretary-General to eliminate any justification for foreign intervention by restoring law and order, as far as possible with the help of the Congo government but without using force or interfering in internal affairs, the Council from the start injected an inherent contradiction into the Congo operation." 10

The UN secretariat acted immediately and established Operation des Nations Unies au Congo (ONUC), a multinational peacekeeping force. It was implemented with surprising efficiency considering the limited communication technology of the day. U.S. transport planes arrived on July $15-30$ hours after the security council resolution had been adopted - with a first contingent of Tunisian soldiers, followed by troops from Ghana, Ethiopia, and Morocco. When Hammarskjold reported to the council July 18, 3,500 UN troops had arrived in Leopoldville. Even at this early stage the differing interpretations of the resolution necessitated a clarifying statement from Hammarskjold. He said that were the UN to act as he proposed, the Belgian government "would see its way to a withdrawal," and that "the Council itself called upon the Belgian government to withdraw its troops." At the same time, he stressed that the UN force was "not under the orders of the [Congolese] government" nor could it be "permitted to become a party to any internal conflict." was met with reservations by African countries, which suspected backtracking on the issue of Katanga. Two days later, in another statement to the council, Hammarskjold reiterated the intention to restore the territorial integrity of the Congo: "The resolution of the Security Council in response to the appeal from the Government of the Congo, clearly applies to the whole of the Territory of the Republic as it existed when the 
Security Council, only a few days earlier, recommended the Congo for admission as a Member of the United Nations." 12

Hammarskjold also proposed that the security council reinforce and clarify the mandate as regards the withdrawal of the Belgian troops. He observed that the security council "did not, as it has done in previous cases, authorize or request the Secretary-General to take specific steps for the implementation of withdrawal-apart, of course from the establishment of the Force," but understood his mandate as the "implementation of its decision on withdrawal." And he continued: "Although I do not consider it necessary, a clarification of my mandate ... might aim at establishing the substance of my mandate on this point and the aim of the Council as regards the implementation of the call for a withdrawal." 13

Another draft resolution was consequently adopted July 22 as Security Council Resolution 145 (1960). It stated that the security council:

(1) Calls upon the Government of Belgium to implement speedily the Security Council resolution of 14 July 1960 on the withdrawal of its troops, and authorizes the Secretary-General to take all necessary action to this effect.

(2) Requests all States to refrain from any action which might tend to impede the restoration of law and order and the exercise by the Government of the Congo of its authority and also to refrain from any action which might undermine the territorial integrity and the political independence of the Republic of the Congo. $^{14}$

By end of July 1960, the UN contingent on the ground amounted to 11,155 soldiers from Ethiopia, Ghana, Guinea, Ireland, Liberia, Morocco, Sweden, and Tunisia. ${ }^{15}$ Hammarskjold was soon confronted with major obstacles, however. In early August efforts to station troops in Katanga failed. Tshombe declared that any entry of UN troops would be met with military resistance. The Belgian government declared "submission" to the council resolutions, which Hammarskjold interpreted to mean only "absence of active resistance," "presenting] us with a serious problem, especially in a situation like the one now created by Mr. Tshombe." ${ }^{16} \mathrm{He}$ also pointed out another challenge:

The central government, in its turn, has shown great impatience. When I presented to them the reasons why, while acting with the utmost speed, I could not responsibly act more speedily, from many quarters the reaction has been one of distrust... thus creating a harmful atmosphere against the major effort of the United Nations in active support of the Republic of the Congo. This dangerous tendency of sowing distrust has not been without support from other quarters outside the Congo. ${ }^{17}$

After lengthy debates, Security Council Resolution 146 (1960), adopted August 9, confirmed the authority vested in the secretary-general and (1) requested him to carry out "the responsibility placed on him," (2) urged the Government of Belgium to immediately withdraw its troops from Katanga,

(3) declared that the entry of the UN force into Katanga was necessary to fully implement the resolution, (4) reaffirmed that the UN force would not "be a party to or 
in any way intervene in or be used to influence the outcome of any internal conflict, constitutional or otherwise," and (5) called on member states "to accept and carry out the decisions." 18

But the situation on the ground became increasingly complicated over the following weeks. After arriving in Leopoldville to initiate the necessary measures, including a visit to Elisabethville to meet Tshombe, Hammarskjold was confronted with expectations that in his view required a clarification as regards the UN mission's impartiality. He released an interpretation of Paragraph 4 of Security Council Resolution 146 (1960), concluding that the UN force could not "be used on behalf of the central government to subdue or to force the provincial government to a specific line of action." ${ }^{\prime 19}$ As a result, cordial relations with Lumumba came to an abrupt end since he felt betrayed and accused Hammarskjold of siding with the Belgians and Tshombe. He declared a state of emergency and appealed for help from the Soviet Union to prepare for an invasion of Katanga. On two occasions, soldiers of the Congolese National Army attacked UN staff.

The rift between Hammarskjold and the Congolese government as represented by the Lumumba faction manifested itself when the security council debated the matter August 21. In response to Hammarskjold's opening statement, the Congolese government's representative, Antoine Gizenga, complained that "if the resolutions of the Security Council continue to be badly interpreted, this will not lead to the liberation of the Congo but to the effective reconquest of the country." 20 In reply, Hammarskjold clarified some issues he considered as "misinformation" and rebutted the accusation that he had not sufficiently consulted the Congolese government. He reminded Gizenga that "the relations between the Secretary-General and the Council are not to be interfered with by any government." And he added that he had gone to the security council "in the best interest of the central government of the Congo.", 21 Finally, after two more critical interventions by Guinea and the USSR, both asking for more military support for Lumumba and for military responsibilities in the UN operations to be delegated to the Congolese army, Hammarskjold elaborated further on 'the question of national governments' wishes as regards the employment of their troops." He said military operations of this kind had to be "under a unified command exercising its authority and its judgement as best it can." He said that if the UN "were to try to meet desires expressed by the very many participating governments" then the operation "would very soon come to a deadlock."22

With the exception of the Soviet Union and Poland, all council members (including Tunisia and Ceylon as spokespersons respectively for Africa and Asia) finally came to support Hammarskjold's management of the operation. But this did not break the impasse.

The rift that erupted between President Kasavubu and Lumumba, resulting in the latter's dismissal as prime minister, caused a deep division in the national government. The ensuing fights over the control of government ended with the assassination of Lumumba. The continued Belgian presence and that of foreign mercenaries in Katanga encouraged Tshombe to remain stubbornly noncompliant with the demand to reintegrate the province into the Congo. Faced with these obstacles, Hammarskjold and the UN force were under growing pressure from UN 
member states to deliver what they wanted according to their diverging interests.

Unable to obtain further guidelines from the security council, Hammarskjold tried to keep the UN force from becoming involved in the local conflicts while seeking to achieve the defined goals - withdrawal of the Belgian troops and the reintegration of Katanga into the Congo. In his efforts to clarify the mandate he repeatedly stressed that "the solution of the problem of the Congo lies in the hands of the Congolese people themselves without any interference from outside." 23 The reality did not reflect this, however, given that by its mandate and presence the UN had already in effect interfered.

\section{The UN and Patrice Lumumba}

When Lumumba was ousted from office as prime minister and the Congolese government fell apart, Hammarskjold and the UN secretariat had to decide how to respond. The Congo mission was by its mandate supposed to act in consultation with the constitutional government. But when President Kasavubu and Prime Minister Lumumba clashed in September 1960, the question was who, by virtue of the position held, could claim to legitimately represent the government. Hammarskjold concluded that the provisional constitution for the Congo, the loi fondamentale, allowed the chief of state (the president) to dismiss the prime minister and appoint a new one if his action was endorsed by at least one minister. This had been the case in the dismissal of Lumumba. One of the highest ranking UN officials serving at the time in the secretariat maintained that "[f]or all practical purposes, it seemed that in the present circumstances the UN must inevitably regard the Chief of State as the only unquestioned constitutional authority." ${ }^{24}$ Resisting demands that the UN should end the secession of Katanga by force and reinstate Lumumba, Hammarskjold declared that "ONUC was not for rent." 25

Lumumba left the house where he was temporarily under the protection of the UN forces in order to mobilize for his return into power. He was captured, tortured, and finally executed in January 1961. The parties implicated in this were the Kasavubu government, the new army strongman Mobutu Sese Seko (who became the dictator of Zaire after a 1965 coup), the CIA, and Belgian soldiers and mercenaries. For the Soviet leader Nikita Khrushchev the non-interference of ONUC showed that Hammarskjold was a lackey of Western interests. Hammarskjold was immediately blamed for not restoring Lumumba to the government of the Congo and later also accused of being responsible for his killing. To what extent the passivity of the UN at least indirectly supported Western interests in removing Lumumba from office and finally eliminating him physically is a matter of debate, as is the extent to which the UN should have protected Lumumba after he had at his own risk abandoned UN protection. As Hammarskjold and others argued, by leaving the secure house to mobilize for the restoration of his political influence, Lumumba again became involved in Congolese politics. Protecting him in this role could therefore have been interpreted as undue interference in the political affairs of the country and therefore a violation of the security council mandate. 


\section{The UN's contested neutrality}

Increasingly under attack by the Soviet Union and its allies but also facing mixed reactions from the nonaligned states, Hammarskjold denied allegations that the UN was acting in support of Western interests and insisted on the need for neutrality and nonintervention in domestic politics. This did not ease the constant pressure exerted on the UN operation by the many parties involved: Western interests, as represented most prominently by Belgium but also by the UK, France, and the U.S.; the British settler minority regimes of the Central African Federation (Northern and Southern Rhodesia and Nyasaland) and apartheid South Africa; and the USSR, which wanted to secure a stake in the resource rich territory or at least prevent the West from establishing another satellite regime. Against this background, Hammarskjold faced growing demands for his resignation (now not only from the Soviet alliance but also increasingly from Belgium, France, and Britain, who saw their vested economic interests at stake).

Following the news of the assassination of Patrice Lumumba, the security council held a series of meetings beginning February 13, 1961, to discuss the situation. On February 15, voicing his frustration over the accusations leveled at the UN mission and the renewed Soviet demands for his resignation, Hammarskjold did not mince his words:

For seven or eight months, through efforts far beyond the imagination of those who founded this Organization, it has tried to counter tendencies to introduce the Big-Power conflict into Africa and put the young African countries under the shadow of the cold war. It has done so with great risks and against heavy odds. It has done so at the cost of very great personal sacrifices for a great number of people. In the beginning the effort was successful, and I do not now hesitate to say that on more than one occasion the drift into a war with foreign-power intervention of the Korean or Spanish type was avoided only thanks to the work done by the Organization, basing itself on African solidarity. We effectively countered efforts from all sides to make the Congo a happy hunting ground for national interests. To be a roadblock to such efforts is to make yourself the target of attacks from all those who find their plans thwarted... . From both sides the main accusation was a lack of objectivity. The historian will undoubtedly find in this balance of accusations the very evidence of that objectivity we were accused of lacking, but also of the fact that very many Member nations have not yet accepted the limits put on their national ambitions by the very existence of the United Nations and by the membership of that Organization. ${ }^{26}$

\section{UN military operations}

The shift to a "politics of murder" 27 was a watershed. Rajeshwar Dayal notes that "it brought about a sharp revision in the concept of the methods to be employed by the United Nations in the fulfilment of its tasks."28 A resolution drafted by Ceylon, Liberia, and the United Arab Republic on behalf of the Afro-Asian group was adopted in a revised version February 21 by nine votes to zero, with the USSR and France abstaining. The operative paragraphs of Security Council Resolution 161 (1961) introduced for the first time the option of use of force as a legitimate last resort: 
The Security Council, [...]

Deeply concerned at the grave repercussions of these crimes and the danger of widespread civil war and bloodshed in the Congo and the threat to international peace and security,

Noting the report of the Secretary-General's special representative (S/4691) dated 12 February 1961, bringing to light the development of a serious civil war situation and preparations therefore,

(1) Urges that the United Nations take immediately all appropriate measures to prevent the occurrence of civil war in the Congo, including arrangements for cease-fires, the halting of all military operations, the prevention of clashes, and the use of force, if necessary, in the last resort;

(2) Urges that measures be taken for the immediate withdrawal and evacuation from the Congo of all Belgian and other foreign military and paramilitary personnel and political advisers not under the United Nations command, and mercenaries. ${ }^{29}$

Operative Paragraph 3 called on states to prevent the departure of military personnel and mercenaries for the Congo from their territories, Paragraph 4 called for an investigation into the circumstances of the death of Lumumba and his colleagues and for the perpetrators to be punished, and Paragraph 5 reaffirmed the earlier resolutions. As a concession to the USSR, no mention was made of the secretarygeneral's responsibility as regards the implementation of the resolution. But the Western members of the council understood Paragraph 5 as implicitly confirming his continued authority. ${ }^{30}$

While Hammarskjold welcomed this resolution "as giving a stronger and clearer framework for United Nations action," he also observed that it did not "provide a wider legal basis or new means for implementation." 31 Instead of being a breakthrough and clarifying the mandate, the resolution complicated matters even more and created another stalemate: both the Congolese government under Kasavubu and Mobutu (who were afraid of being implicated in the killing of Lumumba) and the secessionist Katanga administration under Tshombe vehemently resisted the idea that the UN would have the power to infringe their authority, if necessary by force of arms. Meanwhile, Western states showed no interest in putting pressure on Belgium to accede to the demands for its withdrawal from Katanga. A vigorous diplomatic offensive undertaken by the secretary-general vis-a-vis the Congolese and Belgian governments and the Katangese secessionist leader Tshombe yielded no results. Pressure on Hammarskjold and the secretariat mounted.

The General Assembly discussed the Congo in several sessions from March 7 into April 1961. In response to attacks calling his efforts to implement Security Council Resolution 161 "useless," Hammarskjold replied:

I would be very interested to know what alternatives there are to correspondence and talks when there is a question of pressing on people and authorities the necessity to implement resolutions. Is the alternative military means? If so, what troops would the Secretary-General have been able to use and with what legal authorization ${ }^{32}$ 
Two draft resolutions were introduced by the Afro-Asian group April 5 and 6 and adopted after several amendments April 15, the first condemning

Belgium's failure to withdraw military personnel and political advisers as demanded by the security council and the second calling for further efforts toward reconciliation in the Congo as an alternative to a military solution. ${ }^{33}$ The Assembly also adopted a third resolution to establish a commission of investigation into the death of Lumumba. ${ }^{34}$ Hammarskjold concluded the assembly sessions with a statement regarding the implementation of the resolutions, saying "it would be appropriate to make a distinction between demands, authority, and means" and that "all through the history of the Congo operation demands [had] gone far beyond authorization and authorization far beyond means." 35

Despite slow progress, by early August the defunct Congolese parliament had reconstituted and consolidated a functional modus operandi. But the continued presence of the Belgian military and hundreds of mercenaries in Katanga remained unresolved and had even gained influence. The mounting frustration over the lack of progress finally turned into more desperate efforts, initiated mainly on the ground, to force the foreign collaborators out. On August 24 President Kasavubu, on the advice of Hammarskjold, issued an ordinance "for the immediate expulsion of all non-Congolese officers and mercenaries in the Katanga forces who had not entered into a contractual engagement with the central government." On the same day Prime Minister Cyrille Adoula formally requested UN assistance in executing the ordinance, giving the UN legal authority within the Congo in accordance with the evacuation provision of Security Council Resolution $161 .^{36}$

When a final effort to bring Tshombe to Leopoldville for a meeting with Adoula failed, UN troops, instructed by the secretary-general's special representative in Katanga, Conor Cruise O'Brien, mounted a surprise attack under the code name "Operation Rumpunch." 37 In the early hours of August 28 they occupied strategic points in Elisabethville and other parts of Katanga to seize and repatriate Belgian officers and mercenaries. But instead of completing the operation, the UN forces withdrew, assuming that the Belgian diplomats on the ground would complete the process as they had promised. On realizing their mistake and being confronted with the subsequent radical and swift reinforcement of the "ultra" faction in the white groupings in Katanga, the local UN officials "were either impatient with or did not fully understand" Hammarskjold's reminders of the constitutional restraints on the UN reaction to the crisis. Their plan for action, code-named "Operation Morthor," went considerably beyond the scope of the authority given them from UN Headquarters. ${ }^{38}$

Launched by the UN September 13, 1961, Operation Morthor met a forceful response from the regrouped forces in Katanga. On September 10 Hammarskjold had accepted an invitation from Prime Minister Adoula to visit Leopoldville. Aware that Rumpunch had irritated Western countries, he was keen to meet 
Adoula and have further negotiations with Tshombe. An exchange of cables prior to Morthor suggests he had been involved in the discussions preceding the operation. Cables published by The Guardian show that he had consulted his legal advisor, who warned strongly against such operation as a "violation of the ban against intervention in domestic political conflicts." ${ }^{39}$ But on September 10, 1961, Hammarskjold cabled a colleague to say that "the speed of developments and the stage reached means that short of a change for the better in Katanga we are beyond the point of no return." ${ }^{40}$ While some take this as an endorsement of Morthor, it remains a matter of interpretation whether Hammarskjold explicitly authorized the operation. As often before, he used a semi-oracular kind of language that allowed for differing interpretations. There are, however, sufficient indications that he was involved in the discussion regarding if and how the UN military presence might be instrumental in reversing the secession of Katanga. The governments of the Western states became aware of Hammarskjold's involvement and conveyed their strong disapproval. Dismissing criticism by the U.S., Hammarskjold cabled September 15, 1961, to his close coworker Ralph Bunche at the UN headquarters:

It is better for the UN to lose the support of the US because it is faithful to law and principles than to survive as an agent whose activities are geared to political purposes never avowed or laid down by the major organs of the UN... . Generally speaking, I have one advice and that is that the major powers do not react until they know the facts and further, that they do remember that they are most likely to keep their positions if they respect principles than if they expect others to break them on their behalf or on behalf of the Welenskys. ${ }^{41}$

It is not far-fetched to conclude, as Timothy Scarnecchia does, that the 1961 UN military operations "were seen as a sacrifice of Western economic interests ... in return for Soviet support of a negotiated end to the civil war." ${ }^{42}$ As O'Brien observed:

When Katanga is hurt, money screams, and money has powerful lungs. . Hammarskjold was subjected to the most intense pressure, both psychological and diplomatic, to draw back from what the UN had undertaken - which was in fact the ending of the secession of Katanga by the use of force. ${ }^{43}$

On September 17, Hammarskjold and 15 others (entourage and crew) left Leopoldville on a flight considered risky. Hammarskjold was to meet Tshombe in Ndola to negotiate an end to the Katanga secession. Their plane crashed while approaching the Ndola airport sometime during the night. Diplomatic communication suggests that Hammarskjold's plan could have been to offer a federalist solution to bring back the Katanga province by making it semiautonomous within the Congo, with Tshombe in return being appointed to a high-ranking position. Already alarmed by the two failed military operations of the UN forces, the Western powers would have considered this an even more serious threat to their control over the natural resources in the region. Manuel Frohlich notes that "almost all of the major secret services in the world are at least suspects in one or another theory [about the cause of the crash]" and that 
"[i]n retrospect, Hammarskjold's death becomes singular evidence of the Secretary-General's independence."

\section{Results and lessons of the Congo mandate}

Summing up toward the end of 1960, Colin Legum presented a balance sheet of mixed results. ${ }^{45} \mathrm{He}$ identified five aims of the UN operation. The first, to expel Belgian troops from the Congo, was largely achieved but failed to expel those seconded to the army in Katanga. The second, to provide military assistance to the government by, among other methods, maintaining a pacification line between Katanga and the rest of the Congo, was partly achieved. The third, to restore the unity of the Congo, could hardly be achieved as long as the UN force was restricted to a non-interventional role. This contradiction was obvious from the start and reflected the conflicting interests of the influential member states. The fourth, to provide technical assistance to a functioning government, was perhaps the biggest achievement. And the fifth, to keep the Cold War out of Africa, was obviously not achieved. The Cold War hampered both the formulation and the implementation of the Congo mandate.

In the context of the Cold War dynamics, Hammarskjold constantly sought to uphold the principle of the secretariat's autonomy from the direct influence of member states. When the secretariat, he said, "is regarded as truly international, and its individual members as owing no allegiance to any national government," then it "may develop as an instrument for the preservation of peace and security of increasing significance and responsibilities." ${ }^{46} \mathrm{He}$ also insisted that the fundamental principles laid down in the Charter were of special significance for the practical work of the organization "in relation to countries under colonial rule or in other ways under foreign domination." He said the General Assembly had "translated the principles into action intended to establish through selfdetermination a free and independent life as sovereign states for peoples who have expressed in democratic forms their wish for such a status." ${ }^{47}$

The evidence does not seem to substantiate the claim that Hammarskjold willingly allowed his office and the UN to promote a Western imperialist agenda. If anything it suggests that, then as now, the hegemonic powers seek to influence global policies primarily in their interests. The space the mandate for the UN mission in the Congo provided for differing interpretations was both an advantage and a disadvantage. It failed to set out a clear frame of reference and left too many important aspects unclarified. This in turn increased the range of possible individual decisions and ways of handling matters. This flexible approach ran the risk of being criticized for acting arbitrarily or in a partisan way. The collision of the two blocs at the height of the Cold War over their interests in the Congo turned the UN mission into a battlefield for securing advantages.

The complicated mixture of domestic political rivalries, external influences by other states, an unclear framework for UN intervention and personality clashes had deadly consequences. But while Hammarskjold and the UN failed to end the conflict in the Congo, the intervention at least managed to prevent an escalation 
into a much larger interstate military conflict over the control of geostrategic resources. As Sture Linner put it, "The Congo crisis could easily have provoked armed conflicts in other parts of Africa, even led to a world war. It was Hammarskjold and no one else who prevented that." 48 On the other hand, we should be careful not to overemphasize Hammarskjold's influence, limited as it was by the environment in which his office was forced to operate under the political constellation of the time. Ernest Lefever says we can "speculate that the Congo drama might have turned out quite differently if Hammarskjold had not died" but adds that "evidence suggests that the outcome depended less on the personality of the Secretary-General than on the interplay of external and Congolese interests." 49

Clearly the secretary-general could not be expected to achieve miracles in a polarized world. While persons and personalities matter, the decisive factors for success may lie beyond the direct influence of an individual, and whether the individual can take advantage of these factors will depend on his or her ability to accommodate differing interests. After all, the secretary-general was "never given authority to impose a political solution on the Congo." ${ }^{50}$ A mandate that remains as open and unspecific as the one for the first Congo mission of the UN is potentially a recipe for failure, if not disaster.

\section{Concluding observations}

Several issues raised in this article seem relevant beyond the events of the time and offer ideas on how a mandate may affect the course of an operation. The success or failure of a UN intervention is clearly influenced by the clarity of the mandate, the extent of consensus among influential member states, and the extent to which they support the secretary-general in implementing the mandate.

Hammarskjold understood and executed his office more as general than as secretary. A proactive guardian of the UN Charter, he took the initiative when the security council was reluctant to act. It is very likely that the mandate would have not been adopted if it had not been for his personal initiative. This brings to the fore the role the secretary-general can play if he or she is willing to. Ever since Hammarskjold's terms in office, successive secretaries-generals have been assessed against his performance. It brought to the fore the need to define the interaction between the member states and the secretariat. In executing the Congo mandate, Hammarskjold jealously guarded the independent role of the secretariat.

But the relative autonomy of such leadership, which is able and willing to take responsibility, not only strengthens but also potentially weakens an operation. After all, the implementation of the mandate is to a large extent dependent on a single person. Hammarskjold used a new instrument: he established an advisory board and special representatives to expand the operational scope and his authority. But this added to the vulnerability of the enterprise. The implementation of the mandate became the subject of interpretation not only by member states but also by a circle of persons (dubbed the "Congo Club") in the secretariat and on the ground. Their personalities and loyalties became an 
important secondary factor and led to clashes and questionable judgments with at times dramatic consequences.

Hammarskjold's efforts to retain control of the implementation of the mandate prevented member states from deviating from his understanding of the ONUC operations. For Hammarskjold it would have been inconceivable to delegate the implementation of parts of the mandate to forces outside his command and control, such as NATO or any other partisan organization or state. Besides having sole responsibility for the operations, the secretariat's internal structures allowed for quick communication and action. Largely as a consequence of Hammarskjold's hands-on approach, the secretariat was hardly affected by bureaucratic red tape and could act without delay. Within not much more than a single day, a mandate was adopted and the first contingents of Blue Helmets arrived in the Congo.

Confronted with increased clashes of geostrategic interests between the Western states and the Soviet alliance over the Congo and in particular Katanga, Hammarskjold relied on close cooperation with states from the Afro-Asian group. This made it possible to introduce resolutions mainly through them, which made it more difficult for either of the two Cold War blocs to simply object. Giving weight to the newly independent countries, Hammarskjold in return received trust and support from their leaders. When the secretary-general was confronted with criticism from either of the two blocs, the Afro-Asian group largely remained loyal to him. Similarly, in an effort to reduce dependence on the major powers, Hammarskjold sought new avenues to strengthen his mandate by resorting to the General Assembly instead of relying exclusively on the security council.

The bottom line was that the Congo mission encountered substantial challenges from the international context. During the General Assembly debate during March and April 1961, Hammarskjold summed up the limitations of a mandate that had to reconcile, at least on the surface, potentially conflicting interests within the "first UN" (the member states) while delegating its implementation to the "second UN" (the secretary-general and the secretariat). The difficulties the organization and its secretary-general faced in implementing the Congo mandate remain very much a current challenge. As Hammarskjold observed:

It has been said that the United Nations operation in the Congo is disappointing or even a failure. It seems reasonable to ask those who say so whether the reason for their disappointment is that the Organization has done anything less than it could do, or that elements beyond the control of the Organization have created difficulties which at the present stage of its development are insuperable for the instrument for international cooperation which Members have created in the United Nations, even when that instrument is strained to its utmost capacity. One can blame a mountain climber for his failure to reach the summit when his road has been blocked by an avalanche, but to do so is an irresponsible play on words. ${ }^{51}$ 


\section{Notes}

1. Parts of this article draw on Henning Melber, "Dag Hammarskjold and Africa's Decolonization," in Peace Diplomacy, Global Justice and International Agency: Rethinking Human Security and Ethics in the Spirit of Dag Hammarskjold, ed. Carsten Stahn and Henning Melber (Cambridge, UK: Cambridge University Press, 2014), 255279.

2. Quoted in Kai Falkman, ed., To Speak for the World: Speeches and Statements by Dag Hammarskjold (Stockholm, Sweden: Atlantis, 2005), 71.

3. Telegram dated July 12, 1960, from the president and the prime minister of the Republic of the Congo to the Secretary-General. Security Council Official Records, Fifteenth Year, Supplement for July, August, and September 1960, document S/4382, in Andrew Cordier and Wilder Foote, eds., Public Papers of the Secretaries-General of the United Nations. Volume V. Dag Hammarskjold, 1960-1961 (New York, NY: Columbia University Press, 1975), $18 \mathrm{f}$.

4. Ibid., 19. The 1955 Bandung Conference in Indonesia was the first large-scale meeting of African and Asian states.

5. This article states that "the Secretary-General may bring to the attention of the Security Council any matter which in his opinion may threaten the maintenance of international peace and security."

6. Dag Hammarskjold, "Opening Statement in the Security Council, New York, July 13, 1960," in Cordier and Foote, Public Papers, 21, 22, 23.

7. Security Council Official Records, Fifteenth Year, Supplement for July, August, and September 1960, document S/4387, in Cordier and Foote, Public Papers, 25.

8. Ibid., 26.

9. Maria Stella Rognoni, "Dag Hammarskjold and the Congo crisis, 1960-1961," in Stahn and Melber, eds., Peace Diplomacy, 201.

10.Brian Urquhart, Hammarskjold (New York, NY: Harper \& Row, 1972), $403 f$.

11.Dag Hammarskjold, "First Report on Assistance to the Republic of the Congo, New York, 18 July 1960," in Cordier and Foote, Public Papers, 29, 30.

12.Dag Hammarskjold, "Statement in the Security Council Introducing His Report, New York, 20 July 1960," in Cordier and Foote, Public Papers, 42.

13.Ibid.,43.

14.Ibid., $44 f$.

15. Dag Hammarskjold, "Summary of Composition and Deployment of the United Nations Force in the Congo, New York, 31 July 1960," in Cordier and Foote, Public Papers, 49f.

16. Dag Hammarskjold, "First Statement in the Security Council Introducing His Second Report, New York, 8 August 1960," in Cordier and Foote, Public Papers, 71.

17. Ibid.

18. Cordier and Foote, Public Papers, 76.

19. Dag Hammarskjold, "Interpretation of Paragraph 4 of the Security Council's Third Resolution on the Congo, Leopoldville, The Congo, 12 August 1960," in Cordier and Foote, Public Papers, 87.

20. Security Council Official Records, Fifteenth Year, 887th meeting, in Cordier and Foote, Public Papers, 113.

21. Ibid., 114.

22. Ibid., 120.

23. "First Message to Mr. Tshombe," September 16, 1961. Security Council Official Records, Sixteenth Year, Supplement for July, August, and September 1961, document S/4940/Add.4, in Cordier and Foote, Public Papers, 570.

24. Urquhart, Hammarskjold, 443f.

25. Ryan Irwin, "Sovereignty in the Congo Crisis," in Decolonization and the Cold War: 
Negotiating Independence, eds. Leslie James and Elisabeth Leake (London, UK: Bloomsbury, 2015), 213.

26. "Second Statement After Soviet Demand for His Dismissal," New York, February 15, 1961. Security Council Official Records, Sixteenth Year, 933rd meeting, in Cordier and Foote, Public Papers, 349f.

27. Rajeshwar Dayal, Mission for Hammarskjold: The Congo Crisis (London, UK: Oxford University Press, 1976), 189-214.

28. Ibid., 190.

29. Cordier and Foote, Public Papers, $356 f$.

30. Ibid., 358.

31. "Statement in the Security Council After Adoption of Afro-Asian Resolution," New York, February 21, 1961, in Cordier and Foote, Public Papers, 359.

32. "Third Statement," New York, April 7, 1961, in Cordier and Foote, Public Papers, 433.

33. UN General Assembly resolution 1599(XV), "The Situation in the Republic of Congo," April 15, 1961; UN General Assembly resolution 1600(XV), "The Situation in the Republic of Congo," April 15, 1961.

34. UN General Assembly resolution 1601(XV), "The Situation in the Republic of Congo," April 15, 1961.

35. "Fourth Statement," New York, April 18, 1961, in Cordier and Foote, Public Papers, 437.

36. Ibid., 540.

37. For details see the personal account by Conor Cruise O'Brien, To Katanga and Back: A UN Case History (New York, NY: Simon \& Schuster, 1962), 195ff.

38. Cordier and Foote, Public Papers, 541.

39. A series of stories and reproduced cables were posted on the website of The Guardian, August 17, 2011. See "UN Cable 7 September 1961: Legal Doubts over Operation Morthor," http://www.guardian.co.uk/world/interactive/2011/aug/17/un-cablehammarskjold-katanga-operation-morthor?INTCMP=SRCH.

40. See "UN Cable 10 September 1961: Hammarskjold Gives the Order for Operation Morthor," The Guardian, August 17, 2011, http://www.guardian.co.uk/world/interac tive/2011/aug/17/un-cable-hammarskjold-operation-morthor?INTCMP=SRCH.

41. See "Top Secret UN Cable 15 September 1961: Hammarskjold Rejects American Criticism," The Guardian, August 17, 2011, http://www.guardian.co.uk/world/interac tive/2011/aug/17/un-cable-hammarskjold-american-criticism?INTCMP=SRCH. Sir Roy Welensky was prime minister of the Federation of Rhodesia and Nyasaland and a fierce opponent of the UN's role in the Congo, which he considered a threat to white supremacy in southern Africa.

42. Timothy Scarnecchia, "The Congo Crisis, the United Nations, and Zimbabwean Nationalism, 1960-1963," African Journal of Conflict Resolution 11, no. 1 (2011), 65.

43. O'Brien, To Katanga and Back, 261.

44. Manuel Frohlich, Political Ethics and the United Nations: Dag Hammarskjold as Secretary-General (London, UK: Routledge, 2008), 191.

45. Colin Legum, Congo Disaster (Harmondsworth, UK: Penguin, 1961), $166 f f$.

46. Dag Hammarskjold, "Last Words to the Staff-from Remarks on Staff Day, New York, 8 September 1961," in Cordier and Foote, Public Papers, 564.

47. Ibid., 545 .

48. Sture Linner, "Dag Hammarskjold and the Congo Crisis, 1960-61," in Sture Linner and Sverker Astrom, UN Secretary-General Hammarskjold: Reflections and Personal Experiences. The 2007 Dag Hammarskjold Lecture (Uppsala, Sweden: Dag Hammarskjold Foundation, 2008), 29.

49. Ernest Lefever, Uncertain Mandate: Politics of the U.N. Congo Operation (Baltimore, MD: Johns Hopkins Press, 1967), 30.

50. Ibid., 220. 
51. "First Statement," New York, March 29, 1961, in Cordier and Foote, Public Papers, 420. 